\title{
Parading myths: Imaging New Soviet Woman on Fizkul'turnik's Day, July 1944
}

In this paper ${ }^{1}$ I want to explore the "political physiology"2 of the Soviet female body beautiful, as exemplified in two photographs by N. Volkova and L. Leonidova published on the front page of the weekly sports newspaper Krasnyi sport (Red Sport), 18 July 1944 [Figs 1 \& 2]. Krasnyi sport, published in Moscow, was the official organ of the AllUnion Committee for Physical Culture and Sports Affairs. This particular edition was dedicated to celebratory coverage of the All-Union Day of the Fizkul'turnik (participant in physical culture), Sunday 16 July 1944 . The focus of the front page was the first sports parade to be held at Moscow's prestigious Dinamo stadium since the start of the war in 1941. The event had profound national significance.

Dinamo, the largest sports complex in the USSR, with its own station on the new Moscow metro, was a monument to State promotion of a semi-militaristic national obsession with sport. It was also a symbol of state power and the preeminence of Moscow, the centre of government. ${ }^{3}$ The re-opening signified the removal of the recent threat to the capital posed by the advance of German troops, and was explicitly set in the context of the Soviet invasion of occupied Poland and Belorussia. Actions on the three Belorussian fronts and in Lithuania were reported triumphantly at the bottom of Krasnyi sport's front page. ${ }^{4}$

Despite the apparent patriarchalism of both the newspaper and the Soviet state, and despite reportage of the ecstatic response of the crowd to the entrance of a column of male athletes from the Red Army, there were no soldiers and only two men shown in the front-page photographs of the event. Indeed, the layout of this front page suggested 


\section{Parading myths: Imaging New Soviet Woman on Fizkul'turnik's Day, July 1944}

that all that was heroic, triumphant and hopeful in the USSR was to be perceived as invested in the Soviet athletic girl. The masthead slogan was a quotation from Gorky, extolling her "confident tread", eyes "burning with joy" to live where "the body is brought up to be so fast and beautiful" and full of "heroic fighting spirit". ${ }^{5}$ Beneath this slogan, on the left-hand side was an image of a column of banner bearers, in which the main figures were a shapely young woman flanked by two men, apparently followed by a phalanx of little girls [Fig.1]. On the right-hand side was a photograph of vigorously marching, pubescent teenage girls, possibly aged between 13 and 17 years [Fig.2]. The girl nearest the camera seems androgynous and solemn. The other girls in the front line appear to have more developed figures, but are not yet as well-built as the flag bearer. This picture illustrated the leading article - "The March of Stalin's Youth" - which proclaimed the Moscow event to be a parade of "youth, strength, health and beauty worthy of our great days". 6

In investigating the possible contemporary connotations of these key words in relation to the imagery I will suggest that they constituted a Socialist Realist cultural package. The package arguably projected an historically contingent mythologisation of the female New Soviet Person. This fiction seems to have been partly rooted in constructs of "will", "training" and "self-training" prominent in contemporary Soviet educational psychology as well as in Party propaganda on fizkul'tura, and partly rooted in notions of domestic and national purity and hygiene associated with Soviet woman as mother. The result, I suggest, was an effective, double-edged propaganda sword which contributed to the mystification of discourse on women in contemporary Soviet culture. 


\section{Parading myths: Imaging New Soviet Woman on Fizkul'turnik's Day, July 1944}

Socialist Realism, established at the Writers' Union Congress in 1934 as the sole method of Soviet cultural production, was defined by Andrei Zhdanov, newly appointed Secretary of the Central Committee of the CPSU, as the representation of "reality in its revolutionary development". ${ }^{7}$ Zhdanov, protector of Stalinist cultural orthodoxy from 1934 to 1948, required that Socialist Realism should offer an educational glimpse of the future perfected socialist world, designed to operate as an aspirational model for the consuming masses. Newspapers - whatever their specialist theme - were explicitly positioned as propaganda sites which offered ideologically correct models to their mass readers, through carefully contrived juxtapositions of texts and images. ${ }^{8}$ Newspaper photographs were vehicles of Socialist Realism as much as any poster, painting or monumental sculpture, and unlike these media, photography offered an enhanced credibility to the accompanying texts, through the apparent, direct reference to lived actuality. ${ }^{9}$ In July 1944 , one of the tasks explicitly shared by Socialist Realism and the promotion of fizkul'tura in Krasnyi sport was to temper the Soviet "will to victory". ${ }^{10}$

In the Soviet context of production and consumption, the photographs I have chosen to focus on would have conveyed a complex set of meanings to their audience. Writing within the context of a very different set of power structures than pertained in the USSR in 1944, I can only look at the images through lenses tinted by my interests and concerns with feminism, social history of art and elements of poststructuralist thought in a Western, post-Soviet framework. I can only suggest a possible and inflected reading of what the photographs might have signified in their own context, in the knowledge that 


\section{Parading myths: Imaging New Soviet Woman on Fizkul'turnik's Day, July 1944}

these images remain open to other interpretations arising from different ideological perspectives. My own approach is partly indebted to particular aspects of recent research on Soviet culture that have drawn attention to the potential impact of discourse on health, fizkul'tura and educational psychology on representations of women (and men) in Socialist Realist visual culture. ${ }^{11}$

British art historian, Toby Clark, coined the term "political physiology" to denote political constructs of bodily form that accorded with, and could be used to symbolize, what was currently required from the citizen by Soviet ideology. ${ }^{12}$ These constructs related directly to an abstractly defined, heroic ideal of a future, perfected genus of humankind, the New Soviet Person, which would combine the physical characteristics of health, strength, and beauty, with the mental and moral powers to achieve the highest levels of patriotism and partiinost' (party-mindedness). ${ }^{13}$ Amidst the 1920s' discourse on "social hygiene" and "leftist" eugenics, the question of how to engineer the development of the New Person became central, not just to medical, psychological and educational theory, but also to the fetishisation of sport and physical culture by Party and state. Fizkul'tura, initially linked with military training, was pinpointed by a Party resolution of 13 July 1925 as a means to draw workers and peasants into political and social activities. ${ }^{14}$ Thereafter it was repeatedly cited as the source for engendering qualities and attributes analogous to those of the New Person. ${ }^{15}$

The arts were expected to provide descriptions and visualizations of this ideal. The broad requirement, reinforced in 1934, was for the creation of an array of fictional 


\section{Parading myths: Imaging New Soviet Woman on Fizkul'turnik's Day, July 1944}

"types" standing for ideological constructs connected with age, sex, class and occupation, that responded to shifting state concerns and Party policies. ${ }^{16}$ Propaganda for fizkul'tura was only one aspect of this task.

In the 1930s, some of this visual propaganda took the form of posters exhorting the population to engage in fizkul'tura. Alexander Deineka's poster of 1933, Fizkul'turnitsa, [Fig.3], for example, showed slim, muscular youths and young men shooting, running and motorcycling as a backdrop to the central figure of a slim, muscular young woman throwing a discus. The slogan urged viewers to put more effort into working towards "the new life" and reminded them imperiously: "You may not be able to be an athlete, but it is your duty to be a fizkul'turnik". The general physical ideal for both sexes, youth, slenderness and muscularity, was also, in part, supported by less admonitory forms of visual propaganda relating to the spectacle of the Soviet sports parade, exemplified by Alexandr Rodchenko's photograph of 1936, Female Pyramid [Fig.4], and Aleksandr Samokhvalov's painting of 1937, Fizkul'tura Parade [Fig.5]. The Soviet sports parade was designed to project an affirmation of the Party's goal of creating a renovated humanity. The organization of such events has been described - for example, by Toby Clark and by Aleksandr Zakharov - as an art form in itself, a ritual, symbolic performance that was only marginally about sport. ${ }^{17}$ Representations of sports parades, served to reinforce the significance of these spectacles as affirmations of Party ideology, affording premature glimpses of the future New Person. 


\section{Parading myths: Imaging New Soviet Woman on Fizkul'turnik's Day, July 1944}

While visualizations of the New Person could be either male or female, the construct of the New Soviet Person used masculine linguistic forms (novyi sovetskii chelovek) to signify ostensible gender-neutrality. Thus, for instance, Boris loganson could describe a portrait of Aleksandr Deineka's wife in masculine terms as a representation of a "zhivii chelovek" (living person) ${ }^{18}$ As Attwood has noted, this usage relates to the masculine bias built into the structure of the Russian language ${ }^{19}$ From a post-structuralist perspective, viewing language as that which constructs individual, gendered identities in relation to the dominant ideology in a given culture, the prioritization of masculine linguistic forms can be argued to indicate the intrinsically patriarchal bias of Soviet culture. $^{20}$ That is to say, it suggests an acceptance by both men and women, largely unconsciously, as a result of the operation of language on the formation of their sense of identity, of a power structure in which the male "naturally" takes precedence over the female. On a less theoretical level, there were also intimations in writings on the New Person that not just the linguistic form, but also the primary model, was masculine. A fulsome article by the critic V. Friche in 1918, for instance, described the New Person as "son of light-bringing Prometheus". ${ }^{21}$ The primacy of this male Promethean and Herculean image was reiterated in Gorky's speech to the Writer's Union Congress in 1934, and at the same congress A.I. Stetsky stressed the importance of celebrating male explorers and aviation pioneers, such as Valerii Chkalov. ${ }^{22}$

In the 1930s, visual images of Socialist Realist 'positive heroes' as incarnations of the New Person, were, to some extent, dominated on the one hand by images of the great "fathers" of Bolshevism, especially Lenin and Stalin, and on the other hand by pictures 


\section{Parading myths: Imaging New Soviet Woman on Fizkul'turnik's Day, July 1944}

of heroic male aviators, explorers, scientists, "shock workers" and, after 1935, "Stakhanovites" who followed in the footsteps of the overproductive Donbass coalhewer, Alexei Stakhanov. The rugged features of this hero 'type' can be seen in the first line of men in Samokhvalov's painting [Fig.5], while his legendary strength seems to be illustrated by the men supporting the "female pyramid" in Rodchenko's photograph [Fig.4].

There were, of course many "positive" images of women "heroes", including representations of women occupying traditionally male spaces - tractor-driving, engineering and political speaking. The function of these images was to illustrate the benefits of emancipation within the Soviet state, and the legal equality of rights that became enshrined in the new Constitution of 1936. Discourse around such images tended to favour broad applications of masculine terms, and eschewed anatomical specificity in describing female "political physiologies", as I shall discuss later. These strategies, which problematize attempts to decode Socialist Realist images of women, were not only tied to the notion of equality, but also to the suppression of discourse on sexual difference in Soviet culture after the closure of the Women's Department of the Party (Zhenotdel) in 1930. ${ }^{23}$

Despite the positive propaganda, patriarchal attitudes to women, locating them as inferior and primarily domestic and maternal, permeated Soviet social and political life. ${ }^{24}$ These attitudes were partly rooted in pre-Revolutionary peasant views of women as hardly human and possessions of the patriarchal family. ${ }^{25}$ Early Bolshevik treatments of 


\section{Parading myths: Imaging New Soviet Woman on Fizkul'turnik's Day, July 1944}

the "woman question" had denounced domestic slavery as the source of women's political "backwardness", defining women's emancipation as dependant, not only on political education and paid employment, but also on the provision of state childcare and communal dining rooms. ${ }^{26}$ Yet, during the 1930 s state legislation and Party policy locked women ever more closely into motherhood and domestic duties, while simultaneously demanding their full participation in public life without providing sufficient numbers of the promised facilities. In 1936 for instance, abortion was made illegal and divorce became more difficult, while state rewards were instituted for mothers of many children. $^{27}$ From 1935 onwards, the main thrust of propaganda for the Stakhanovite movement acknowledged the possibility of women workers as participants, but emphasized their chief role to be that of the supportive "housewife-activist", a role also stressed for wives of "engineering-technical" workers by the Obshchestvennitsa movement $1936-41 .^{28}$

Nuanced references to this contradictory mindset can be found in some of the "positive" images of the 1930s New Woman. For instance, Olga Eiges' women's day poster from 1938, Long live Stalin's constitution! Long live the enfranchised women of the USSR! [Fig.6] ${ }^{29}$, celebrates the right and, indeed, duty of Soviet women to combine motherhood with public service and paid employment. Women, however, continued to be responsible for domestic and child-care duties from which men were regarded as exempt. The Soviet construct of "equality" thus placed a double burden upon women, which effectively ensured the dominance of men over the political and economic spheres of Soviet life, despite the preponderance of women in the population and sharp 


\section{Parading myths: Imaging New Soviet Woman on Fizkul'turnik's Day, July 1944}

increase of women entering paid employment during and after the First Five Year Plan $(1929-33) \cdot{ }^{30}$

Another hint of women's perceived subordinacy was embodied in the gendering of symbolic representations of the two basic Soviet political classes, the proletariat and the peasantry in the 1930s. ${ }^{31}$ The proletariat, positioned as the more advanced of the two classes, was commonly represented by a male image, while the peasantry was symbolized by a female figure. ${ }^{32}$ Perhaps the most powerful example of this approach is provided by Vera Mukhina's giant sculpture, The Industrial Worker and the Collective Farm Girl, that surmounted the Soviet pavilion at the Paris exhibition in 1937 [Fig.7]. While the interlocking, upraised hammer and sickle imply the unity and solidarity of the two classes, the figure of the peasant girl is smaller than that of the proletarian, and her stride does not reach quite so far forward.

Mukhina's image of the industrial worker seems to combine the dynamic, revolutionary stride of Boris Kustodiev's famous painting from 1920 of the heroic Bolshevik [Fig.8], with the youthful political physiology of the hunky Stakhanovite worker "type". In doing so, she raised this "type" to a more generalized symbolic image of heroic Soviet identity, that was potentially available as a model for representing Soviet triumph in $1944 .{ }^{33}$ Returning to the front page of Krasnyi sport, 18 July 1944, it is interesting to note potential, passing references to this model. The leading article, "The March of Stalin's Youth", for instance, describes the Red Army fizkul'turniks as having: "Bodies bronzed with sunburn, muscled torsos, powerful hands, marching in unison, creating the 


\section{Parading myths: Imaging New Soviet Woman on Fizkul'turnik's Day, July 1944}

impression of might". ${ }^{34}$ In addition, the photograph depicting flag bearers [Fig.1] has as its focal point the figure of a man, bare-chested and forward-striding like Mukhina's proletarian [Fig.7], with the flag pole held strongly away from his body in a manner reminiscent of Boris Kustodiev's Bolshevik [Fig.8].

Given the context, it seems initially surprising that this image should not have a more dominant position on the front page. It seems to fit well with the very patriarchal orientation of the newspaper, which elsewhere extended to a preference for using the term otechestvo (fatherland) to refer to the native land, rather than using the feminized term rodina (motherland) more commonly used in Pravda, Izvestia and Party wartime propaganda. ${ }^{35}$ It also fits with the message of the Red Army's successfully aggressive stance in the war, and with the clear definition of fizkul'tura as a necessary 'preparation of a physically strong generation, with great powers of endurance for the Red Army' offered in the front page editorial, 'For the further growth of fizkul'tura'. For the unnamed journalist and the spectators at the Dinamo stadium, the entry of this column of heroes had been the high spot of the parade, greeted with tumultuous applause. Yet, despite these factors, primacy was given to images of teenage girls [Fig.2] to express the claim that "the fizkul'tura parade itself was a marvellous testimony of the power and might of our people". ${ }^{36}$ Moreover this primacy seemed to follow a precedent set in the previous day's edition of the Party newspaper, Pravda, which had also illustrated reportage of the event with a photograph of a marching troupe of (slightly older) teenage girls or young women from the Dinamo sports club [Fig.9]. ${ }^{37}$ 


\section{Parading myths: Imaging New Soviet Woman on Fizkul'turnik's Day, July 1944}

Given this precedent, it seems likely that the photographs in Krasnyi sport were deliberately referring back to the established visual genre of the sports parade, for celebrating and affirming Party goals. One aspect of this genre, as acknowledged and criticized in Olyesha's novel Envy, 1927, was the potential for male voyeuristic, visual pleasure in spectating semi-clad women's bodies. ${ }^{38}$ Soviet censorship in the 1930s placed strict controls over the representation (and description) of the female body. ${ }^{39}$ Judging from the visual evidence, any hint of nipples beneath clothing was to be avoided in all representations. Too much emphasis on big breasts and hips - the peasant ideal of female pulchritude - was also banned. ${ }^{40}$ Within these limits, however, representations of female participants in sports parades, such as those offered by Rodchenko and Samokhvalov [Figs 4 \& 5], did offer the male viewer rare opportunities to get pleasure from looking at bare arms and legs, and at costumes that revealed the shape of the female body. The photographs in Krasnyi sport [Figs 1 \& 2] had similar potential. The busty banner bearer, for instance, seems closest to the allowable representation of the popular ideal, as exemplified in Samokhvalov's painting by the buxom woman in shorts marching next to the male banner holder [Fig.5]. The girls in the main photograph, by contrast, are closer to the more androgynous appearance of the girls in Rodchenko's Female Pyramid [Fig.4]. Indeed, a tangential reference to visual pleasure is given in "The March of Stalin's Youth" where the correspondent notes the entry into the stadium of the Krasnoe znamya club (who may or may not be the girls in the photograph): "Young girls in refined/graceful (iziashchnykh) sports costumes", which is then contrasted with the physical ruggedness of the heroic Red Army troop. ${ }^{41}$ 


\section{Parading myths: Imaging New Soviet Woman on Fizkul'turnik's Day, July 1944}

On the one hand, the contrasting modes of describing the appearances of the girls and the men seem to hint at a common perception, that the desirable qualities of women were different from those desirable in men. On the other hand, the unwillingness to refer to the female body in describing these qualities, exemplifies the refusal to refer to sexual difference inherent in contemporary discourse on the New Person. The front page also contains other examples of this. The caption to the photograph of marching girls, for example, calls them "young fizkul'turniki", a masculine word used as neutral rather than using the feminine word fizkul'turnitsy. The article 'The March of Stalin's Youth' only uses devushki (girls) twice, mainly preferring to use masculine or masculine/neutral terms such as podrostki (youths/teenagers/young girls). ${ }^{42}$ Even when the two sexes are distinguished from each other, their qualities and characteristics are claimed to be identical: "everywhere, strong, suntanned girls and youths, everywhere the firm confident step of people boldly looking into the future". ${ }^{43}$

More important than the dutiful echo of the Gorky slogan about "confident tread" is the emphasis on the future. The references to youths/teenagers/young girls, tied mainly to images of secondary school-age girls as symbols of hope for the future, chimes in neatly with the more practical vein of the editorial, which calls for more participation of schoolchildren in sport. $^{44}$ In relation to this, the main photographic image seems to become more significant as a Socialist Realist device. A carefully chosen photograph could simultaneously reinforce the declaration of the 1936 constitution, that socialism had been achieved, and also stand as a metaphor for continued development into the bright future. Viewed thus, the images of these teenage girls then might be understood 


\section{Parading myths: Imaging New Soviet Woman on Fizkul'turnik's Day, July 1944}

as representing the nascent stage of the promised New Person, whose emergence was guaranteed by their "youth, strength, health and beauty".

To justify and elaborate on such a reading, and to unpack the keywords, it is necessary to go back into Soviet educational psychology of the 1930s and early 1940s. By this time psychology had been severely purged of its 1920s inclination towards environmental determinism, its connection with physiology and most of its major journals. ${ }^{45}$ Mikhail Kalinin - politburo member and President of the Presidium of the Supreme Soviet - appeared to become a major Party spokesman for the renovated discipline through press reportage of his speeches on education. Indeed, on 11 July 1944, the masthead of Krasnyi sport quoted Kalinin on the need to broaden participation in the fizkul'tura movement. ${ }^{46}$ Meanwhile, the journal Soviet Pedagogy became a major site for theoretical publications on education. ${ }^{47}$

The new style of Soviet psychological theory focused largely on child development, and gave preeminence to will, training and self-training as the main factors in determining the (correct) development of each individual's consciousness. Much obeisance was made to the activist and voluntarist elements in Lenin's theorisation of epistemology the so-called Theory of Reflection - which defined knowledge as acquired by interaction with the world, and consciousness as the ability to rise above immediate concerns to focus on future goals. ${ }^{48}$ 


\section{Parading myths: Imaging New Soviet Woman on Fizkul'turnik's Day, July 1944}

In 1939, for example, L.A. Gordon - a Soviet psychologist who set out the basic formulation of Soviet motivational theory ${ }^{49}$ - effectively argued that the development of consciousness depended on the development of the right sort of 'interests', based on social - rather than biological - needs, and consciously located in the concrete historical context of the individual's position within society at a given moment. ${ }^{50}$ Exertion of will was a necessary factor in this process, but the construct of will invoked was neither the liberal European notion of "free will" nor Nietzsche's concept of the "will to power", but rather a conscious and rational recognition of necessity ${ }^{51}$ Through the writings of leading child-psychologist S.L. Rubinshtein and the enduring influence of the ideas of educational theorists Lev Vygotsky and Anton Makarenko, Soviet psychology appeared to treat motivation of the will as derived from training and self-training, not just within the education system, but also through the family and through play. ${ }^{52}$ Within this mode of thinking, there seemed to be two significant elements of motivation, explicitly theorised in the late 1940s as "duty" - a knowledge of what ought to be done for the good of society - and "ideals" - role models to copy. "Ideals" were to be understood as particularly important motivations for self-training in the sense that their behaviour and values should be objects of voluntary emulation. ${ }^{53}$

For the psychologist K.N. Kornilov, the results of acquiring correct interests, needs and ideals was to be seen in collective and disciplined behaviour. ${ }^{54}$ In relation to this, the image of the collectively marching girls might be seen not only as a sort of "proof" of the correctness of education and upbringing implied by the Gorky slogan, but also, in accordance with the designated role of the Soviet press, to offer an "ideal" role model 


\section{Parading myths: Imaging New Soviet Woman on Fizkul'turnik's Day, July 1944}

underscoring the current "duty" of Soviet schoolchildren. Their duty was to engage with fizkul'tura, to become healthy - as the Pravda article put it, to become "suntanned, wellbuilt and trained" - and to attain strength and physical fitness as called for in the 18 July Krasnyi sport editorial. ${ }^{55}$ Herein, I suggest, lay a transcendent, moral beauty of ideological correctness, invested in a tangible manifestation of patriotism and partiinost'.

The physiological aspect of this has some interesting implications in relation to the engineering of the New Person. Although Soviet psychology was now separated from the discipline of physiology, psychology continued to make little differentiation between mind and body, in keeping with its materialist basis. Training the body - for example through fizkul'tura - was thus a means to train the mind and the moral faculties of the individual and to promote a continuous improvement in the vigour of the Soviet nation. This idea seems to have some roots in aspects of Soviet "leftist" eugenics discourse that were explicitly favoured by the Party in the 1920s and continued to be supported in the 1930s, despite denunciations of eugenics as "fascist" and "bourgeois racism". ${ }^{56}$

On the one hand, it connects with the "social hygienist" beliefs of N. A. Semashko, Commissar for Health until 1930, that the combination of fizkul'tura with "extensive use of sun, air and water" was a crucial means to improve the nation's capabilities. ${ }^{57}$ Where it differs is in replacing Semashko's mechanistic notion that individuals would be changed by merely changing the environment ${ }^{58}$ with the idea that change also required the engagement of the individual's will. On the other hand, it also links with Lamarckian ideas of the inheritability of acquired characteristics. These had been greeted 


\section{Parading myths: Imaging New Soviet Woman on Fizkul'turnik's Day, July 1944}

enthusiastically in 1928 by the Commissar for Enlightenment, Anatoly Lunacharsky, as a model for leftist eugenics ${ }^{59}$, and by 1938 were becoming dominant in Soviet biology through the activities of Trofim Lysenko. ${ }^{60}$ It was, apparently, on the basis of Lysenko's theories that Ukrainian psychologist G. S. Kostiuk had argued that, not only were there no limits to the possibilities of training and self-training, but also learned abilities might even be, in part, genetically transferable. ${ }^{61}$ Within this discourse the New Person seemed to be positioned as something that could be self-created rather than selectively bred. Krasnyi sport's photographic images of marching girls - youthful products of correct training and self-training - could be argued to offer evidence that this was so and thus stand as a visual refutation of the eugenics policies employed by the enemy.

My argument so far offers some possible clues to the "political physiology" offered in the main photograph, in relation to the Soviet cult of youth. It does not, however, give any insight into why girls rather than boys should be targeted as the prime image - by both the photograph and the masthead slogan from Gorky. In relation to the cult of youth, biological sex and gender were ostensibly immaterial. Soviet psychological theory went to great lengths to avoid distinguishing between the sexes. Freudian constructs of children as sexual beings were rejected. Instead, the psychology of child development held to a mythology of childhood innocence and treated children -including teenagers as being of "neutral gender". ${ }^{62}$ Pavlov had maintained that all people were born equal irrespective of sex or race and given the right training and environment could all develop the same abilities and powers. ${ }^{63}$ This sort of thinking not only underpinned Soviet psychology of the late 1930s-40s, but also fed into the construct of the New Person in 


\section{Parading myths: Imaging New Soviet Woman on Fizkul'turnik's Day, July 1944}

the 1930s and was, arguably, partly responsible for the lack of engagement with sexual difference therein. The implied lack of need to address sexual difference was apparently reinforced by the declaration of equality contained in the 1936 Constitution, and enthusiastically iterated in the annual Party statements between 1936 and 1944, commemorating International Women's Day (8 March) ${ }^{64}$

All of this provides aspects of context for the lack of sexual differentiation I have already noted in the leading article of Krasnyi sport. The images, however, are recognizable as girls and the slogan from Gorky seems to underline that there is something particularly important about the young fizkulturnitsa. To arrive at a possible reading of what this might be, it is necessary to look at other aspects of Party and State policy and at nuanced statements about women in the press and other propaganda sources.

However gender-neutral Soviet educational psychology purported to be, the Soviet educational system of the early 1940 s told a different story. Single-sex education, abolished in 1918, was reintroduced in 1943-4 for all ten grades at senior secondary schools in 72 major cities and industrial complexes (lasting until 1954). According to contemporary spokesman, Eugene Medynsky: "Co-education hinders the adaptation of the school program to the different rates of physiological development of boys and girls. It prevents adequate treatment of certain psychological differences and the necessary differentiation of training of boys and girls for practical activities". ${ }^{65}$ While boys were taught technical subjects, only the girls were taught domestic science, for, as was asserted in Soviet Youth News Service, October 1943: "the girls will have to manage 


\section{Parading myths: Imaging New Soviet Woman on Fizkul'turnik's Day, July 1944}

their homes" ${ }^{66}$ Other legislation of 1944 - laws giving different rights to legitimate and illegitimate children and the institution of the Motherhood medal for "heroic" mothers of many children - reinforced the primary significance of the role of woman as mother within a traditional family structure, which had been set in place by the same Constitution which proclaimed women's equality with men. ${ }^{67}$ On the patriotic fizkul'tura front this equality was also somewhat nominal, since the physical fitness awards, "Ready for Defence and Labour" (GTO) and "Be Ready for Defence and Labour" (BGTO), were apparently graded according to age and sex. ${ }^{68}$

The point I want to make here, is that these data indicate a social structure in which differential gender roles not only existed, but also were encouraged. As intimated by Olga Eiges' women's day poster [Fig. 6], women were not only expected to work but they were also expected to be mothers. ${ }^{69}$ Motherhood became a more pressing concern in the face of demographic issues such as the falling birthrate and the wartime reduction of the male population. ${ }^{70}$ As the tide of war turned in the Allies' favour, Party propaganda relating to 8 March can be seen to drift to ever greater emphasis on motherhood as the primary role of Soviet woman. This reached a post-war peak in Sovetskoe iskusstvo, 8 March 1946, with a rapturous statement about Soviet motherhood accompanied by a reproduction of Nina Vatolina's poster depicting victorious Soviet womanhood as a soft-featured mother with a baby [Fig.10]. ${ }^{71}$

I am not suggesting that the main photograph in Krasnyi sport was explicitly about motherhood, but rather, that one of the things that might make images of young girls 


\section{Parading myths: Imaging New Soviet Woman on Fizkul'turnik's Day, July 1944}

special is the nuance that their present patriotism and party-mindedness would ensure that they accepted, and were fit for, the next stage of their "duty" - to be mothers, as well as workers. In this respect, the subsidiary photograph of the flag bearers [Fig.1] appears to hint at the next stage of the desired development, transformation into busty young women ready to consort with hunky New Men. The physiological potential for motherhood, while emphasized in the Pravda photograph [Fig.9], however, seems less important to Krasnyi sport. The focus on teenage girls in the main photograph and the inclusion of a pre-teenage girl in the picture of the banner bearers, suggests that, as well as this nuance of future motherhood, there also may have been reference to another aspect of contemporary gender differentiation, involving constructs of vulnerability and purity, relating to both women and children.

In the USSR, as in Britain, women, particularly but not exclusively mothers with children, were the focal images of defence propaganda during what the Russians called the Velikaia Otechestvennaia voina (Great Patriotic War). Otechestvennaia, although usually translated as 'Patriotic', comes from the root otets (father) and conveys a sense of 'fatherland'. In juxtaposition with this masculinised notion of war, the object of defence was sometimes mythologised into a transcendent construct of the rodina (motherland). This was a feminized, organic and essentially subordinate aspect of Soviet national identity, frequently pictured as a peasant woman - as in Iraklii Toidze's famous poster from 1941, Your Motherland Calls to you [Fig.11]. ${ }^{72}$ Occasionally, however, women were emotively depicted as fragile objects needing male protection, as in the 1941-2 propaganda campaign "Hitler is the most evil enemy of all women". This 


\section{Parading myths: Imaging New Soviet Woman on Fizkul'turnik's Day, July 1944}

campaign generated images such as F. Antonov's poster, reproduced in Literatura $i$ iskusstvo in 1942, with its implications of raped sweethearts reinforced by the slogan: "Fighters of the Red Army! You will not give up your loved ones to infamy and dishonour by the Hitlerite soldiers" ${ }^{73}$ [Fig. 12]

Beyond the most immediate ideological and personal appeal of feminised aspects of defence propaganda, I suggest, there also may be a reference to an enculturated "rhetoric of purity" concerning women, which also fed into the antipathy to discussion of women's bodies and sexuality in official Soviet discourse. Costlow, Sandler and Vowles have intimated that this rhetoric of purity had its origins in Russian society before 1917 and continued throughout the Soviet era and into the $1990 \mathrm{~s} .{ }^{74}$ In the $1920 \mathrm{~s}$ it was reinforced by "social hygienist" campaigns against venereal disease and abortion, that identified the good/pure woman as a monogamous heroine of domestic cleanliness, who had her babies in hygienic hospitals and maternity homes provided by the state. ${ }^{75}$ As Victor Buchli has noted, this seems to have entrenched an assumed equivalence between moral and domestic hygiene as sources of the nation's health, and womens' assumed responsibility for both. ${ }^{76}$ In relation to such cultural assumptions, and given on the one hand the feminised nature of defence propaganda, and on the other hand, the use of terms such as "Fascist filth" to describe the enemy, it seems highly likely that images of women might evoke, even if subconsciously, vestiges of this construct of purity. ${ }^{77}$ 


\section{Parading myths: Imaging New Soviet Woman on Fizkul'turnik's Day, July 1944}

Is there perhaps a reference to the construct implicit in the passage in "The March of Stalin's Youth" which notes the "refinement/gracefulness" of the young girls' sports costumes? It does not seem unreasonable to suggest that the description conjures up not only a sense of pleasurable decorativeness, but also an implicit sense of decorum and propriety, which might be regarded as an attribute of physical and moral hygiene. Following on from this, admittedly tenuous, argument it would be possible to suggest that the special propaganda value of the photographic image in Krasnyi sport may lie in its double emphasis on purity, by reference to a mythology of childhood innocence, reinforced by the connotations of femaleness.

In the course of investigating the front page of Krasnyi sport 18 July 1944, I have argued that it may be seen as a Socialist Realist package projecting a particular "political physiology" of the New Soviet Person in relation to the context of the Soviet invasion of occupied Poland. The focal image of marching pubescent girls would seem to evoke aspects of ostensibly gender-neutral discourse on the function of fizkul'tura within the cult of youth, while gaining extra propagandist force, I suggest, by implicit reference to elements of sexual discrimination in Soviet culture.

The main photograph, by its heroic upwards angle and context, can be argued to transform a documentary snapshot of real Soviet girls into a representation of the New Person in its imago stage, a symbol of hope for the future. In the text this seems to be signified by the investment of marching youth with the attributes that it was their "duty" to develop - strength and health - and with the quality that the dutiful pursuit of these 


\section{Parading myths: Imaging New Soviet Woman on Fizkul'turnik's Day, July 1944}

afforded them - beauty. The feminisation of the image could be read as not only asserting an affirmation of the new single sex education system (at least for some city children) as right for this purpose, but also as drawing in an additional, specifically nuanced future outcome of present dutifulness - for girls to become workers and, most importantly, mothers - producers of the next generation of New Person.

The notion of strength invoked seems to be only partly physical, tied to powers of speed and endurance gained from bodily fitness. Strength thus gained seems, however, to be conflated with moral and ideological strength, the ability derived from training and selftraining to channel individual will into a national "will to victory". For teenage schoolgirls, with reference to the BGTO fizkul'tura programme, it was not, perhaps, so much about current readiness for battle, but more about becoming ready for the future task of postwar reconstruction, which would be their inheritance. ${ }^{78}$ This vision of strength in the process of development has, I suggest, a connotation of vulnerability related to defence propaganda, that is enhanced by the feminized imagery.

Perhaps the most significant element of combined strength and vulnerability projected through the imagery was the intertwined notion of health. This also seems to have been a two-tier construct. Acquisition of health/strength seems to have been specifically located in the contact of the skin with the sun through collective outdoor activity. The text, however, seems to remind the reader that this exposure of the body, particularly the female body, should be done within the confines of modesty and decorum. I suggest that, in this respect, the image operates as a metaphorical confirmation that the 


\section{Parading myths: Imaging New Soviet Woman on Fizkul'turnik's Day, July 1944}

purity and future racial/social/moral hygiene of the nation has been successfully preserved without recourse to "fascist" eugenics.

The beauty resulting from the dutiful acquisition of strength and health, and the maintenance of purity, appears to transcend biology and physiology. There seems to be a strong sense in which the body was to be perceived as beautiful if it had the requisite qualities of strength and health displayed in the appropriate form and context, because this represented patriotic and party-minded engagement with "duty", deriving from the right sort of "interests" and "ideals". The masthead slogan from Gorky and the editorial emphasis on the young fizkul'turniks' devotion to "the Motherland, the Bolshevik Party and the great Stalin" suggest that the beauty of the flesh was positioned as a natural concomitant of a transcendent moral and ideological beauty - as it were, a beauty derived from a correct upbringing, within the Soviet social and political system. ${ }^{79}$

The 'political physiology' of the main photograph that I have speculatively outlined here in relation to the key terms - youth, strength, health and beauty - seems to me to offer two interlinked levels of propagandist motivation to the readership of Krasnyi sport. First of all, in relation to contemporary Soviet psychological theory, the image may be argued to represent an "ideal" of "duty" for children, especially girls, to model themselves upon, and consequently for mothers to encourage children to emulate, and for fathers to ensure that this is done. Secondly, the image may be argued to offer a double helping of encouragement to men, the main targets of defence propaganda, by affirming the success of their efforts so far, and presenting the successfully preserved 


\section{Parading myths: Imaging New Soviet Woman on Fizkul'turnik's Day, July 1944}

objects of defence as worthy of further, and this time, aggressive, military action - in effect providing a spur to the 'will to victory'. For them, the "ideal" role models were the hunky Stakhanovites in the subsidiary photograph, and the Red Army soldiers referred to in the text.

In its own context - 18 July 1944 - the package of images and text in Krasnyi sport was embedded in the networks of Soviet power by its direct linkage to the State/Party apparatus of publication and censorship, and by its contribution to the bonding of desires and representations within Soviet culture. While it might offer the mainly masculine readership an opportunity to revel in the spectacle of the busty banner bearer, and to some extent in the developing figures of the teenage girls in the main phoptograph, the content of the texts directed the reader to serious, moralistic reading of these bodies as metaphors for all that was good, triumphant, victorious, strong, healthy and beautiful about the Soviet state itself. The whole package called upon the contemporary reader to participate or collude in a group affirmation of collective identity.

From my own standpoint, however, the package represents an historically significant example of the patriarchal mystification of discourse on women within Soviet culture. The images seem to constitute a means to share falsified knowledge relating to the honoured status, equality and emancipation of Soviet women, veiling over and perpetuating their second-class existence, by turning it into an "ideal". ${ }^{80}$

(6560 words) 
Parading myths: Imaging New Soviet Woman on Fizkul'turnik's Day, July 1944

\section{Endnotes}

${ }^{1}$ Some of the research presented in this paper relates to a larger research project entitled "Sex and Socialist Realism", funded by the British Arts and Humanities Research Board, February 2002-January 2003.

${ }^{2}$ Toby Clark, "The 'New Man's' body: a motif in early Soviet culture," in M. Cullerne Bown and B. Taylor, Art of the Soviets. Painting Sculpture and Architecture in a Oneparty State 1917-1992 (Manchester and New York, 1993), 46.

${ }^{3}$ Mike O'Mahony, "Representing Fizkul'tura: Sport and Soviet Culture from the First Five-Year Plan to the Great Patriotic War 1929-1945" (Ph.D diss., Courtauld Institute of Art, University of London, 1998), 197, 230-31, 254, 283, 299, 301, 332.

4 "Za nedel'ia. Na frontakh Otechestvennoi voiny," Krasnyi sport, 29, Tuesday 18 July 1944, 1.

${ }^{5}$ A. M. Gorky, cited on the masthead, Krasnyi sport, 29, 1.

6 "Marsh' stalin'skoi molodezhi," ibid.,1-2.

${ }^{7}$ A. Zhdanov, "Soviet Literature. The Richest in Ideas. The Most Advanced Literature," in H.G. Scott, ed., Soviet Writers Congress 1934. The Debate on Socialist Realism and Modernism (1935; reprint ed., London, 1977), 21. 
${ }^{8}$ M. McAndrew, "Women's Magazines in the Soviet Union," in B. Holland, ed., Soviet Sisterhood (London, 1985), 78, 80; Pat Simpson, "On the Margins of Discourse? Visions of New Socialist Woman in Soviet Art 1949-50," Art History 21, 2 (June 1998): 249.

${ }^{9}$ Photography as a medium that compels belief is discussed in: G. Clark, The Photograph (Oxford, 1997), 20; D. Slater, "Photography and Modern Utopia," in C. Jencks, ed., Visual Culture (London, 1995), 222.

10 "Uchites' u frontovnikov," Krasnyi sport 28, 11 July 1944, 1; "Velikaia tema iskusstva," Literatura I iskusstvo 8, 19 February 1944, 1.

${ }^{11}$ Among the most useful sources are: L. Attwood, The New Soviet Man and Woman. Sex Role Socialisation in the USSR (Bloomington, 1990); J. Riordan, Sport in Soviet Society (Cambridge, 1977) and Sport, Politics and Communism (Manchester, 1991); O’Mahony, op. cit.; T. Clark, 33-50.

12 T. Clark, 45-6.

13 Ibid., 46.

${ }^{14}$ Riordan (1977), 106. 
${ }^{15}$ See for example Pravda, 13 June 1937, 1.

${ }^{16}$ Zhdanov, 20; V. Bonnell, Iconography of power. Soviet Political posters under Lenin and Stalin (Berkeley, Los Angeles \& London, 1997), 38-9, 42-3.

${ }^{17}$ T. Clark, 40; A. Zakharov, "Mass Celebrations in a Totalitarian System," in A. Efimova and L. Manovich, eds, Tekstura. Russian Essays on Visual Culture (Chicago and London, 1993), 208-16.

${ }^{18}$ B. Ioganson, "O zhivopisi", Sovetskoe iskusstvo 22, 24 May 1946, 2.

${ }^{19}$ Attwood, 14. See also F.M. Borras \& R.F. Christian, Russian Syntax. Aspects of Russian Syntax and Vocabulary (Oxford, 1971), 4-5, 15.

${ }^{20}$ This perspective has its roots in the theoretical writings of Ferdinand de Saussure, Jacques Lacan, Louis Althusser and Michel Foucault relating to the role of language in creating identity, and is explained most clearly in C. Weedon, Feminist Practice and Poststructuralist Theory (Oxford, 1994), 21-32, 126-7, 148.

${ }^{21}$ V. Friche, "V poiskakh novoi krasoty", Tvorchestvo 1-2 (1918): 5.

${ }^{22}$ M. Gorky, "Soviet Literature," Soviet Writer's Congress 1934, 35-6; A. I. Stetsky, 
Parading myths: Imaging New Soviet Woman on Fizkul'turnik's Day, July 1944

"Under the Flag of the Soviets, Under the Flag of Socialism," ibid., 268-9. See also

Clark, 43; J. Haynes, New Soviet man. Gender and Masculinity in Soviet Cinema (Manchester, 2003), 53-61. It is interesting to note that, out of eleven paintings and sculptures to be awarded the first Stalin Prizes in 1941, only two contained images of women: Vera Mukhina, The Industrial Worker and the Collective Farm Girl, 1937, and Alexei Efanov, An Unforgettable Meeting, 1938.

${ }^{23}$ In announcing this closure, Lazar Kaganovich, first secretary of the Moscow gorkom, declared that henceforth, propaganda should treat Soviet woman 'not as woman but rather as party worker, fully equal': E. Wood, The Baba and the Comrade. Gender and Politics in Revolutionary Russia (Indianapolis \& Bloomington, 1997), 213. See also: J. Riordan, "Introduction," in I. Kon \& J. Riordan, eds., Sex and Russian Society (London, 1993), 2; I. Kon, "Sexuality and Culture," ibid, 23-4; M. \& A. Stern, Sex in the Soviet Union, trans. M.E. Heine, (London, 1981), 40; Attwood, 1-3.

${ }^{24}$ It would be incorrect to say that the Party was unaware of, or unconcerned about this situation. Maxim Gorky, for instance, in 1934 acknowledged the need to eradicate lingering patriarchal notions of woman as domestic slave: Gorky, "Soviet Literature", 53-

4. Yet this attitude survived throughout the Soviet period. Women who entered areas of employment traditionally perceived as male, such as construction work on the Moscow metro or tractor driving, may have been lauded by Party propaganda, but were subject to harassment in the workplace by both men and other women for their 'unfeminine' activities, and the percentage of women kolkhoz managers remained 
minimal even during the war (it rose from 3\% to $12 \%$ in 1943 but had receded to $6 \%$ by 1960): B. Evans Clements, Daughters of the Revolution (Illinois, 1994), 66-7, 70-71, 106; D.L. Hoffman, Peasant Metropolis: Social Identities in Moscow 1929-41 (Ithaca, 1994), 119.

${ }^{25}$ This attitude is most succinctly expressed in the Russian proverb: 'A chicken is not a bird and a woman (baba) is not a human being', Wood, 16.

${ }^{26}$ This line of argument was put forward not only by Lenin, but also by prime movers in the Zhenotdel such as Nadezhda Krupskaia, Aleksandra Kollontai, Inessa Armand and Aleksandra Artiukhina: Wood, 33, 37, 38, 210; Clements, 74.

${ }^{27}$ S. Fitzpatrick, Everyday Stalinism. Ordinary Life in Extraordinary Times: Soviet Russia in the 1930s (Oxford \& New York, 1999), 152-6.

${ }^{28}$ L. H. Siegelbaum, Stakhanovism and the Politics of Productivity in the USSR, 193541 (Cambridge, 1988), 241. For reportage of the inaugural conference for obshchestvennitsy see: “Zamechatel'noe soveshchanie”, Pravda, 10 May 1936, 1; "Pered soveshchaniem zhen inzhinero-tekhnicheskikh rabotnikov tiazheloi promyshlennosti", ibid.; Pravda, 11 May 1936, 1-3. In 1939, however, the domestic bias, shifted to an emphasis on preparing women to do men's work in preparation for the war: Fitzpatrick, Everyday Stalinism, 156-63. 
Parading myths: Imaging New Soviet Woman on Fizkul'turnik's Day, July 1944

29 "Enfranchised" is not a literal translation of ravnopravnaia (equal-in-rights), but its English meaning seems closer to the Russian word's implication of legal and civil rights than "emancipated" which emphasizes liberation.

${ }^{30}$ V. Buchli, An Archaeology of Socialism (Oxford and New York, 1999), 28; Clements, 76, 80, 144-5, 147.

${ }^{31}$ These classes were somewhat nominal. As Sheila Fitzpatrick has argued, there was a more complicated class system operating within Stalinist society. S. Fitzpatrick, "Ascribing Class: The Construction of Social Identity," Journal of Modern History 65 (December 1993): 745-770.

${ }^{32}$ S. Fitzpatrick, Everyday Stalinism, 10, 15, 160: G. Hosking, A History of the Soviet Union 1917-1991 (1985;London 1992), 24-5, 376.

${ }^{33}$ While my linkage of the Bolshevik and Industrial Worker images is speculative, Mukhina did emphasise the elevation of 'type ' into 'image' as crucial to the representation of the New Person in Soviet monumental sculpture. V. I. Mukhina, "Tema i obraz v monumental'noi skul'pture", Sovetskoe iskusstvo 2, 14 November 1944, 2.

34 "Marsh' stalin'skoi molodezhi," 1.

35 The masthead of Krasnyi sport, 27, 4 July 1944, 1, for example, carried the phrase 
"Slav'sia, otechestvo nashe svobodnoe!" ("Celebrate, our fatherland is free!").

36 "Za dal'neishii rost fizkul'tury," Krasnyi sport, 29, 18 July 1944, 1.

${ }^{37}$ G. Shirokova (TASS), "Vystupivshie fizkul'turnikov sportivnogo obshchestva 'Dinamo' “, photograph accompanying A. Vit, “Vsesoiuznyi den' fizkul'turnika," Pravda, Monday, 17 July $1944,4$.

${ }^{38}$ Iu. Olesha, Envy (1927), trans. J.C. Butler (Moscow, 1988), 150-51.

${ }^{39}$ M. \& A. Stern, 123, 150-54.

${ }^{40}$ Ibid., 65.

41 "Marsh' stal'inskoi molodezhi”.

${ }^{42}$ The alternation between between podrostki (13-19 years) and devushki (15+) also gives a fuzzy sense of the age range under discussion. Throughout this essay I have chosen to use the terms 'girl/girls' to refer to the focal image under discussion not only to differentiate between the age/physiologies represented in Figs $1 \& 2$, but also because, in British English, these words best convey the sense of, as yet, untapped promise that seems to be celebrated in both the masthead slogan by Gorky and in the main article in Krasnyi sport. 'Girl', for instance denotes 'unmarried woman' whereas 
the phrase 'young woman' does not: The Chambers Dictionary (Edinburgh, 1999), 677. Moreover, 'girl' is commonly used with regard to teenage females either in or eligible for secondary education.

43 Ibid..

44 "Za dal'neishii rost fizkul'tury". The girls in the photograph may not, in actuality, have received any secondary education since, by 1939 , only $8.5 \%$ of the female population had attended High School (as opposed to $13 \%$ of the male population). Because they lived in Moscow, however, they were more likely to have received some secondary education than were girls from rural areas - by $193919 \%$ of urban females over the age of 9 had received secondary education as opposed to a mere $3.5 \%$ in rural areas. The percentage of girls entering secondary education rose dramatically after the war: Clements, 72, 100, 106, 145.

${ }^{45}$ R. A. Bauer, The New Man in Soviet Psychology (Cambridge, Mass., 1952), 93,96, 128-30; J. McLeish, Soviet Psychology. History, Theory, Content (London, 1975), 159.

${ }^{46}$ M. I. Kalinin, cited on masthead, Krasnyi sport 28, 11 July 1944, 1.

${ }^{47}$ McLeish, 167.

${ }^{48}$ Bauer, 16-17, 93, 103-5, 132. 
${ }^{49}$ Ibid., 139.

${ }^{50}$ L.A. Gordon, "Potrebnosti i interesy," Sovetskaia pedagogika, 8-9 (1939): 134-5.

${ }^{51}$ Arguments characterizing the Stalinist construct of will as Nietzschean have been advanced by G. Giunter, "Geroi v totalitarnom kul'ture," in K. Kopanski, ed., Agitatsiia za schast'e (Dusseldorf and Bremen, 1994), 71 and by G. Revzin, "Devushka moei mechty," Iskusstvo, 3 (1990): 39-43. These arguments, used to criticize Soviet images of muscular women as being 'monstrous', however, seem to have no basis in Stalinist psychological theory. See also, P. Simpson, "Soviet Superwoman in the landscape of liberty: Aleksandr Deineka's Razdol'e, 1944," in A. Gruetzner Robins and S. Adams, eds., Gendering Landscape Art (Manchester and New York, 2000), 87-101.

${ }^{52}$ McLeish, 170-171; Attwood, 50-51, 57.

${ }^{53}$ Bauer, 140-41.

${ }^{54}$ K.N. Kornilov, "Vopros ob obuchenii i vole," Sovetskaia pedagogika, 5-6 (1942): 54.

${ }^{55}$ Vit, "Vsesoiuznyi den' fizkul'turnika”; "Za dal'neishii rost fizkul'tury."

${ }^{56}$ Ia. A. lakovlev, "O darvinizme I nekotorykh antidarvinistakh," Pravda 101, 12 April 
1937, 3-4, simultaneously published in Sotsialisticheskoe zemledelenie, 12 April 1937,

2-5; Academicians A. N. Bakh, V. A. Keller, Professor Kh. S. Koshtoiants, Candidates of Biological Science A. Shcherbakov, P. Dorzortseva, E. Polikarpova, N. Nuzhdin, S. Kraevoi \& K. Kosikov, "Lzheuchenym ne mesto v akademii nauk," Pravda 11, 11 January 1939, 4; M. B. Adams, "Eugenics as a social medicine in Revolutionary Russia. Prophets, patrons and the dialectics of discipline-building," in S. G. Solomon \& J. F. Hutchinson, eds., Health and Society in Revolutionary Russia (Indianapolis \& Bloomington, 1990), 219.

${ }^{57}$ N. A. Semashko, Health Protection in the USSR (London, 1934), 60; N. A. Semashko, Nauka o zdorov'e (1922; Moscow, 1926), 53-4; D. Joravsky, The Lysenko Affair, (Cambridge, Mass., 1970), 259.

${ }^{58}$ A. E. Gaissinovitch, "The Origins of Soviet Genetics and the Struggle with Lamarckism, 1922-29," trans. M. B. Adams, Journal of the History of Biology 13, 1 (Spring 1980): 0009.

${ }^{59}$ A. V. Lunacharskii, "Kak voznik stsenarii 'Salamandriia'," Sovetskii ekran 1 (1924): 4; Gaissinovitch, 0048.

${ }^{60}$ M.B. Adams, "Eugenics in Russia 1900-1940," in M. B. Adams, ed., The Well-Born Science. Eugenics in Germany, France, Brazil and Russia (Oxford \& New York, 1990), 196, 198. 
${ }^{61}$ G. S. Kostiuk, "The Role of Inheritance, Environment and Training in the psychic Development of the Child," Sovietskaia pedagogika 6 (1940), 21, cited in Bauer, 145.

${ }^{62}$ L. Engelstein, The Keys to Happiness. Sex and the Search for Modernity in fin-de Siecle Russia (Ithaca \& London, 1992), 232; M. \& A. Stern, 125.

${ }^{63}$ Attwood, 44-5.

${ }^{64}$ See for example, Postanovlenie TsK VKP(b), "O mezhdunarodnom zhenskom dne 8 Marta," Pravda, 5 March 1944, 1; Professor I. Trainin, "The Stalin Constitution: II The Soviet Woman", Soviet War News, 493, Friday 19 February 1943, 3.

${ }^{65}$ E. Medynsky, "Schools and Education in the USSR," American Sociological Review, 9, 3, (June 1944): 287, 291.

${ }^{66}$ Soviet Youth News Service, 5 (October 1943): 2.

67 "A State Act of Outstanding Political Significance. New Soviet Maternity and Child Welfare Charter," Soviet War News, 905, 11 July 1944, 8; "July", Soviet Calendar 1917-1947. Thirty Years of the Soviet State (Moscow, 1947), (no page numbers).

${ }^{68}$ Soviet War News, 912, Tuesday 18 July 1944, 4. 
${ }^{69}$ K. Nikolaeva, "Sovetskaia zhenshchina v Otechestvennoi voine," Pravda, 8 March 1944, 3.

${ }^{70}$ The Soviet birthrate had been falling since the Revolution: Clements, 151. The antiabortion law of 1936 produced a slight rise in the birthrate but this fell steeply during the war: Fitzpatrick, Everyday Stalinism, 41, 155. Nove estimates Soviet war losses at approximately 27 million people: A. Nove, An Economic History of the USSR 1917-1991 (1969, revised ed. London, 1992), 291. A high proportion of those killed were men, reducing the male population from $48 \%$ in 1939 to $44 \%$ by 1951: Clements, 145 .

${ }^{71}$ Postanovlenie TsK VKP(b), "O mezhdunarodnom zhenskom dne - 8 Marta," Sovetskoe iskusstvo, 11, 8 March 1946, 1.

${ }^{72}$ Simpson, 'On the Margins of Discourse', 258-9.

${ }^{73}$ Literatura i iskusstvo, 33, 15 August 1942, 1.

${ }^{74}$ J. T. Costlow, S. Sandler and J. Vowles, eds., "Introduction", Sexuality and the Body in Russian Culture (Stanford, 1993), 27, 36-8.

${ }^{75}$ F. L. Bernstein, "Envisioning Health in Revolutionary Russia: The Politics of Gender in Social Enlightenment Posters of the 1920s," The Russian Review 57 (April 1998): 
202, 209, 211-13, 215.

${ }^{76}$ V. Buchli, 81, 83, 112

${ }^{77}$ Soviet War News, 617, Tuesday 20 July 1943, 3.

78 "Velikaia tema iskusstva".

79 "Za dal'neishii rost' fizkul'tury".

${ }^{80}$ Some readers might find this conclusion rather negative, given the important contribution made by the USSR to the defeat of fascism and to the higher levels of legal rights and employment opportunities available to women under Stalin than were accessible by western women during that period. It is worth noting, however, that the entrenched 'ideal' of Soviet womanhood seems to have contributed to the proliferation of explicit sexism and exploitation of women characteristic of the post-Soviet condition: B. Pilvre, "Taming the phantom of feminism in Estonia" in A. Dimitrikaki, P. Skelton \& M. Tralla (eds), Private Views. Spaces and Gender in Contemporary Art from Britain and Estonia (London, 2000), 67-8; M. Castells, The Information Age, 3 vols (Oxford, 2000) 3, End of Millennium,158-9, 180; 'Prevention of traffic in women democracy programme', TACIS, www.tacisinfo.ru/en/fiches/women/, 12/03/02. 
Parading myths: Imaging New Soviet Woman on Fizkul'turnik's Day, July 1944

Parading myths: Imaging New Soviet Woman on Fizkulturnik's Day, July 1944 Illustrations

1. N. Volkova \& L. Leonidova, photograph "The Celebration of All-Union Fizkulturniks' Day at the Dinamo Stadium Moscow started with a ceremonial march-past. In the photographs: on the left - column of banner bearers... ", Krasnyi sport, 29, (18 July 1944): 1. British Newspaper Library, Colindale, London. 


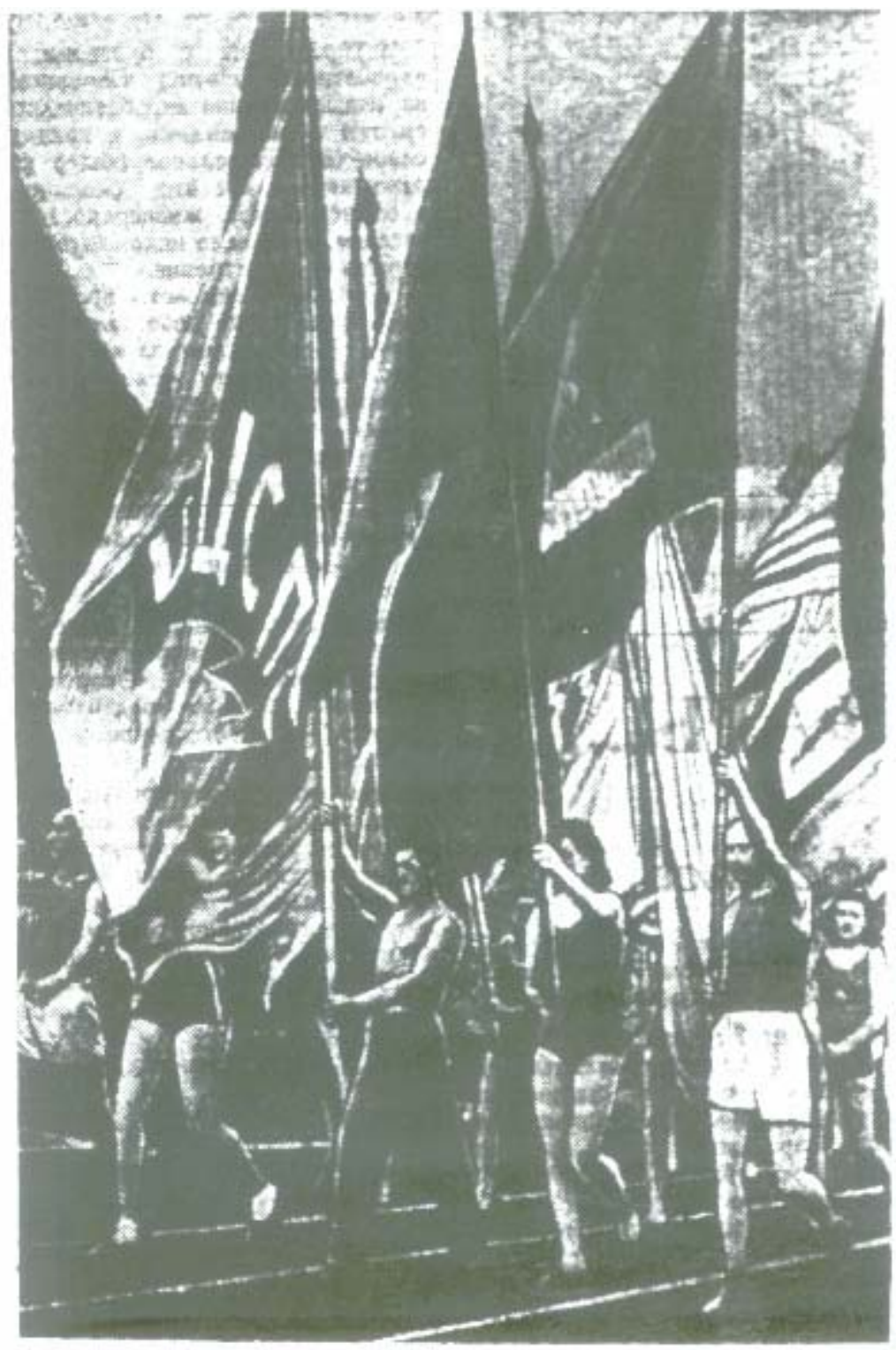

2. N. Volkova \& L. Leonidova, photograph, “...on the right - young fizkulturniks,” Krasnyi Sport, 29 (18 July 1944): 1. British Newspaper Library, Colindale, London. 


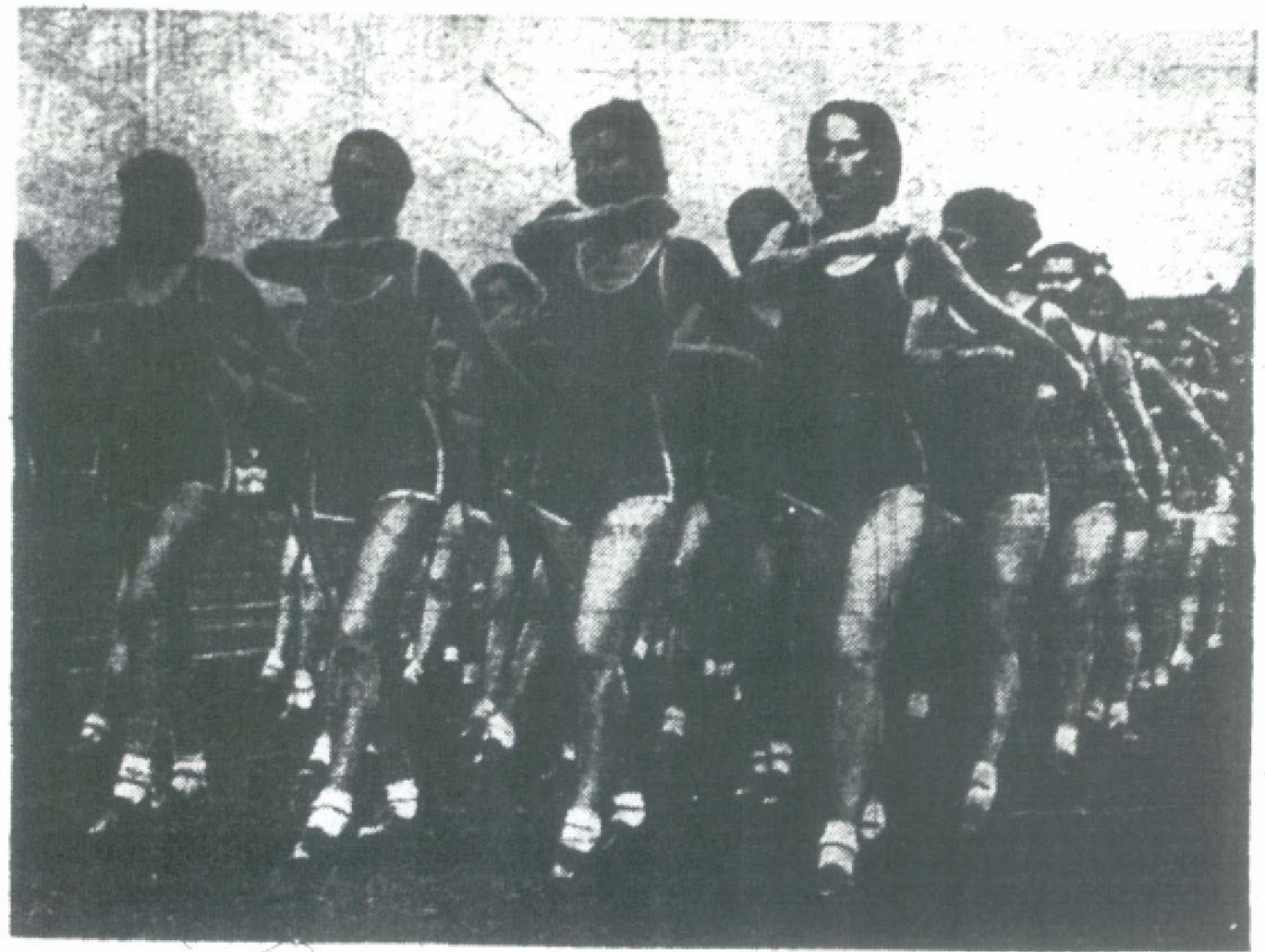

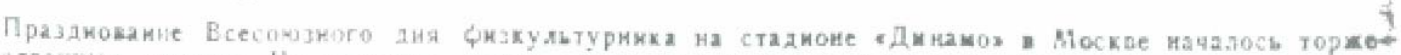

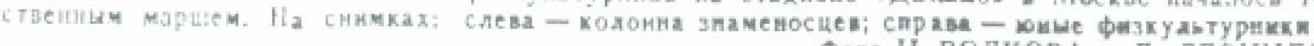
Фото Н. ВОЛКОВА и Л. ЛЕОННДОВА.

3. A.Deineka, Fizkulturnitsa, Poster 1933, $100 \times 73$. State Russian Museum, St Petersburg. V.P. Sysoev, Deineka (Leningrad: 1971), plate 11. 


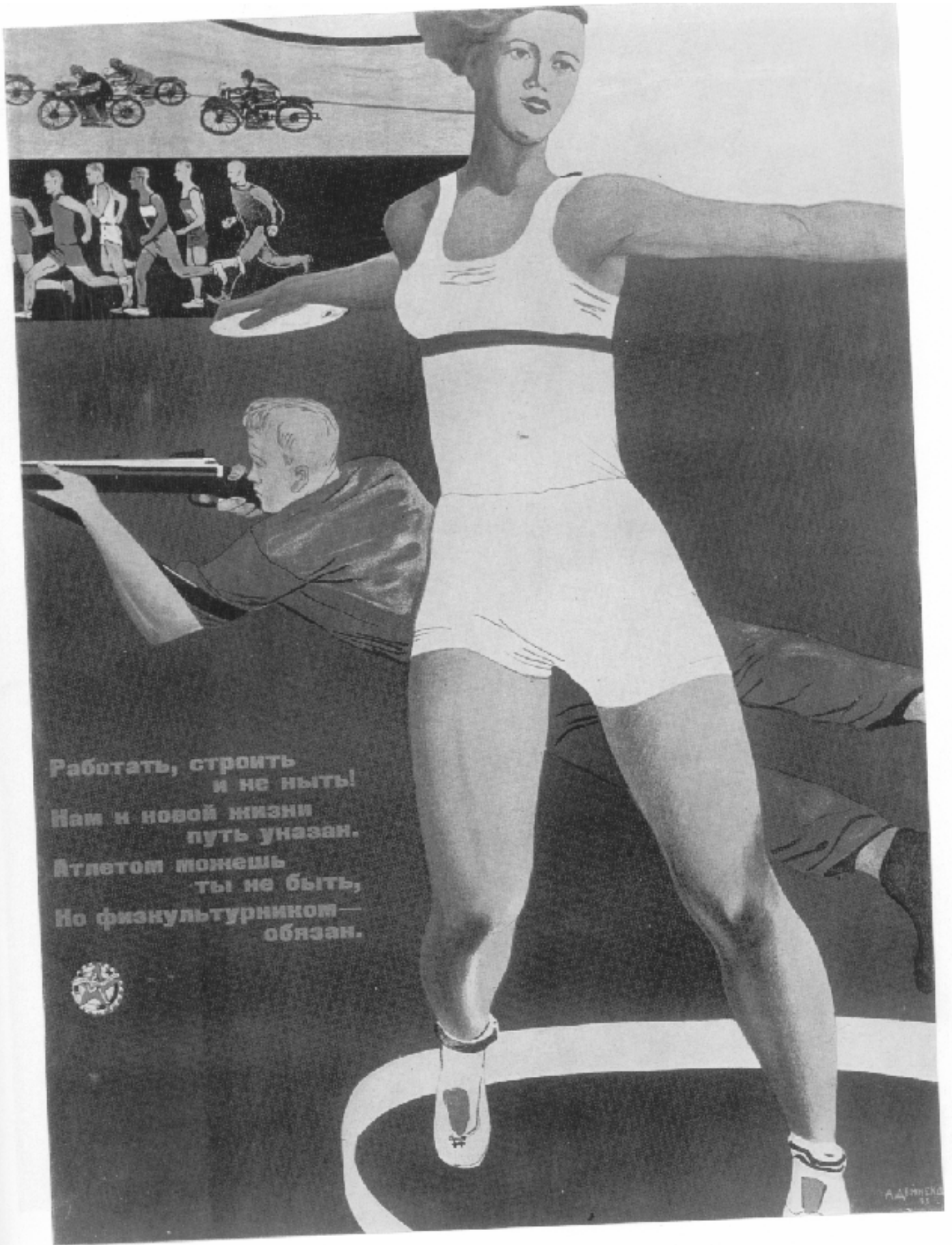

4. Female Pyramid (1936), 40 x 29.5cm. Photograph by Aleksandr Rodchenko. (The Rodchenko and Stepanova Archive, Moscow; VAGA, New York) 
5. Physical Culture Parade (1937), oil on canvas $305 \times 372 \mathrm{~cm}$, (detail). Painting by Alekandr Samokhvalov. (State Russian Museum, St Petersburg)

6. Olga Eiges, Long live Stalin's constitution! Long live the equal in rights women of the USSR!,1938, poster for 8th March, International Women's Day. Russian State Library, G. Prorokhov, Art under Socialist Realism (Rosemont, New South Wales: 1995), 27, plate 11.

7. Vera Mukhina, The Industrial Worker and the Collective Farm Girl (Rabochii i kolkhoznitsa), 1937 V.I. Mukhina, Industrial Worker and Collective Farm Girl, 1937, Soviet Pavilion, Paris Exhibition 1937, stainless steel, h.24m (now in Moscow), Novosti. Carlos Sáenz de Tejada, illustration from Agustín de Foxa, Canción de la Falange, 1939, Biblioteca de Catalunya, Barcelona (card produced for Art \& Power, Hayward Gallery London, 1995. Photo, Richard Napier.)

8. Boris Kustodiev, Bolshevik, 1920, oil on canvas, $101 \times 141 \mathrm{~cm}$, State Tretiakov Gallery, Moscow, M. Cullerne Bown, Socialist Realist Painting (New Haven and London: 1999), 57, plate 52) 
9. G Shirokova (TASS) photograph, "The advancing fizkulturniks from the Dinamo sports club," Pravda (17 July 1944): 4. British Newspaper Library, Colindale, London.

\section{Всесоюзный день физкультурника}

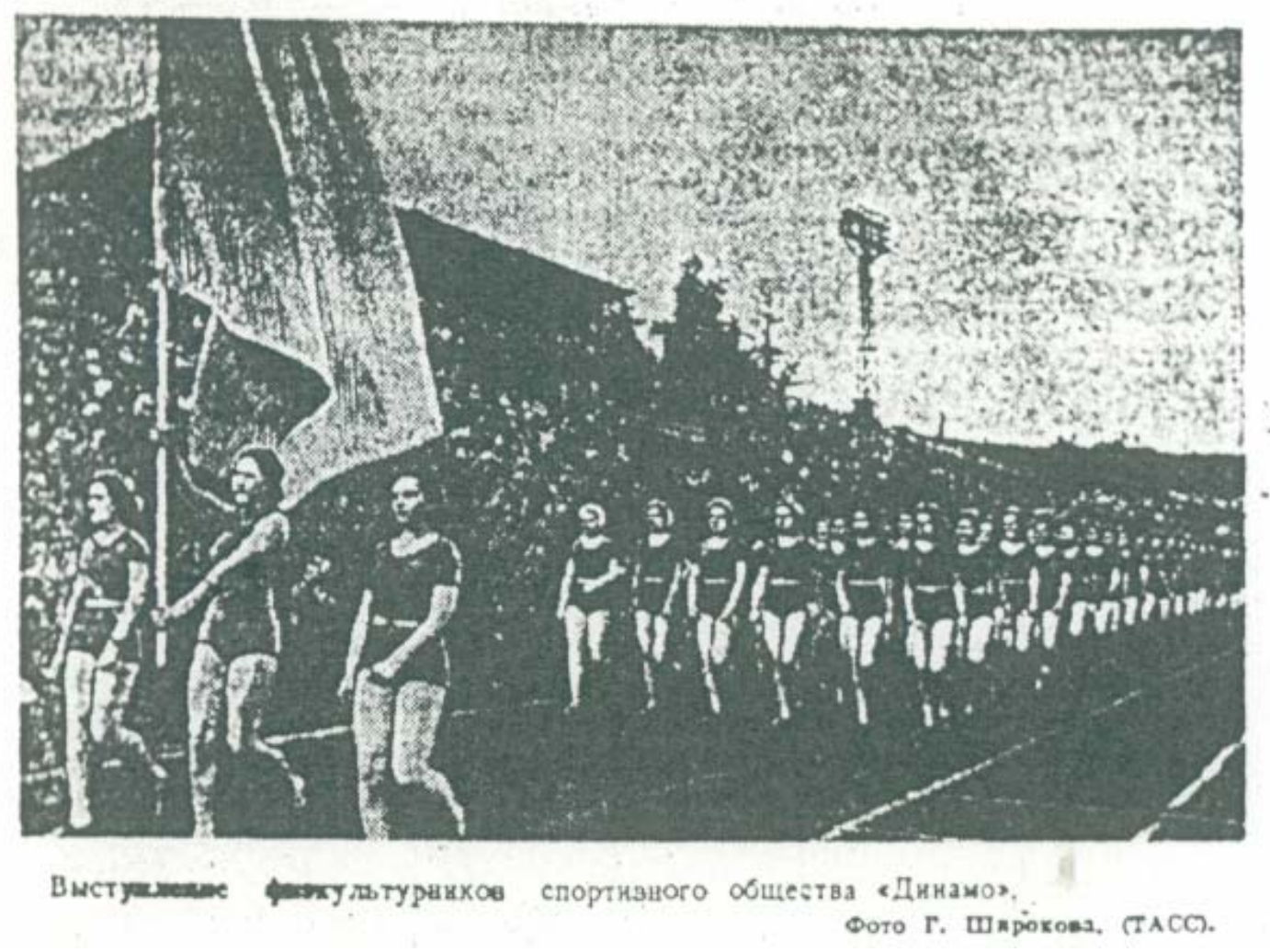

10. Nina Vatolina, International women's day poster, reproduced in Literatura $i$ iskusstvo, 11 (8 March 1946): 1, British Newspaper Library, Colindale. Russian 
State Library, N. Snopkov et al., Zhenshchin v russkom plakate (RSL, Moscow: 2001), 94.

11. Iraklii Toidze, Your Motherland Calls to you, 1941, poster, pencil charcoal and tempera on paper, $100 \times 70 \mathrm{~cm}$, State Tretiakov Gallery \& Russian State Library, Moscow, N. Snopkov et al., Zhenshchin v russkom plakate (RSL, Moscow: 2001), 72 .

12. F. Antonov, "Fighters of the Red Army! You will not give up your loved ones to infamy and dishonour by the Hitlerite soldiers," poster, Iskusstvo publishing house, reproduced in Literatura i iskusstvo, 33 (15 August 1942): 1. 